\title{
OPERATIONAL RESEARCH OF ADSORPTION CHILLER AGGREGATE UTILIZING HEAT FROM DISTRICT HEATING TO PRODUCE CHILLED WATER FOR AIR CONDITIONING
}

\section{BADANIA EKSPLOATACYJNE SORPCYJNEGO AGREGATU CHŁODNICZEGO WYKORZYSTUJĄCEGO CIEPŁO SIECIOWE DO WYTWARZANIA CHŁODU DLA POTRZEB KLIMATYZACJI*}

\begin{abstract}
The article contains the results of an experimental installation operating examination, aiming at proving the advisability of using an adsorption chiller aggregate to produce chilled water for air conditioning systems. The subject of the survey was an installation supplied from heat distribution network in the summer season, utilizing the network heat, which occurs in overabundance in off-heating seasons. The way of adsorption chiller aggregates functioning as well as the results of examinations on the influence of water temperature in supplying and discharging the heat from the aggregate on its refrigeration power and Coefficient of Performance have been shown in the article. The survey has been done for the range of network water temperatures up to $70^{\circ} \mathrm{C}$, which means typical for the off-heating season in most heat distribution networks in Poland. The received results indicate the possibility of utilizing, being in overabundance in summer season, network heat to supply adsorptive cooling appliances producing ice water for the needs of air conditioning.
\end{abstract}

Keywords: district heating, chilled water, air conditioning, adsorption process

\begin{abstract}
Artykuł zawiera wyniki badań eksploatacyjnych instalacji pilotażowej, mających wykazać celowość zastosowania adsorpcyjnego agregatu chtodniczego do wytwarzania wody lodowej na potrzeby systemów klimatyzacyjnych. Obiektem badań była instalacja zasilana z sieci ciepłowniczej w okresie letnim, a więc wykorzystująca ciepło sieciowe, którego jest nadmiar w okresach pozagrzewczych. W artykule przedstawiono sposób działania agregatów adsorpcyjnych oraz wyniki badań wplywu temperatur wody w obiegach zasilania oraz odprowadzenia ciepła z agregatu na jego moc chłodnicza oraz sprawność wytwarzania chtodu COP (Coefficient of Performance). Badania wykonano dla zakresu temperatur wody sieciowej do $70^{\circ} \mathrm{C}$, czyli typowej dla okresu pozagrzewczego w większości sieci ciepłowniczych w Polsce. Uzyskane wyniki wskazuja na możliwość zagospodarowania, będacego w nadmiarze w okresie letnim, ciepła sieciowego do zasilania adsorpcyjnych urządzeń chtodniczych, wytwarzajacych wodę lodowa na potrzeby klimatyzacji.
\end{abstract}

Stowa kluczowe: sieć ciepłownicza, energia chłodnicza, klimatyzacja, proces adsorpcji.

\section{Introduction}

Heat distribution networks are complexed structures being a combination of pipes of various diameters, which carry the heat, by a thermodynamic factor, from the source producing the network heat to its terminal receivers. The heat is used to technological, warming and municipal purposes. The basic problem of heat distribution networks in summer season is the decrease in the demand for heat, which is mostly used for preparing domestic warm water. A discussion on the possibility of increasing heat distribution networks load by utilization the heat to produce chilled water by using absorptive as well as adsorptive aggregates has taken place for a couple of years. In Scandinavian counties the interest is particularly visible, mainly because of higher temperatures of the heating factor [17]. The data shown in publications $[7,13]$ are a proof of an increasing tendency of network coolants supplies. In the majority of Polish cities, too low temperature of distribution network water, which in summer season varies from 66 to $70^{\circ} \mathrm{C}$ in the source, and in fact is $8^{\circ} \mathrm{C}$ lower reaching the receiver, restricts the usage of adsorptive air conditioning systems working in decentralized units. The minimum temperature of a factor which supplies absorptive, bromine-lithium refrigerators is about $72^{\circ} \mathrm{C}$, whereas the effective work is possible at temperatures $85-90^{\circ} \mathrm{C}$ [20]. Increasing the temperature of a heating factor to parameters $90 / 55^{\circ} \mathrm{C}$, typical for Scandinavian countries, would lead to increasing the heat loss during the transfer [21,22]. The problem of low temperature of water supplying sorptive cooling aggregates in summer season do not apply to silica gel adsorptive appliances, whose performance is possible for a heating factor at temperatures just above $55^{\circ} \mathrm{C}$.

Designing and development of adsorptive cooling systems, based on the usage of silica gel and sulfur dioxide began in the $20^{\text {th }}$ of the previous century [14]. A modification of the construction and applying various pairs of adsorbent-adsorbate have been done in order

(*) Tekst artykułu w polskiej wersji językowej dostępny w elektronicznym wydaniu kwartalnika na stronie www.ein.org.pl 
to increase the efficiency of coolant production as well as the cooling power. Experimental examination of basic parameters influencing the ability to absorb silica gel in a grainy state and after covering a flat surface with it have been shown in article [5]. The evaluation of the possibility to increase the adsorptive efficiency of refrigerating appliances by intensifying heat transport to the border of an adsorbent deposit and heat exchanger pipes has been carried out. Many publications, among others $[1,3,4,12,16,23]$ deal with numeric modelling and mass and energy flow simulation in adsorptive refrigerating aggregates, most often of double and triple-deposit.

The described models are based on some main fore designs, among others:

- the law of mass and energy conservation,

- adsorption balance depending on pressure and temperature,

- the kinetics of the adsorption process.

The equations of a kinetic model, Linear Driving Force [19] are used most often to describe the process of adsorption. The adsorptive balance as a function of pressure and temperature is determined by using the equations formulated by Chihara and Suzuki [2].

The possibilities of using adsorptive cooling aggregates supplied by the heat from distribution networks have been described in publications $[10,20]$. In publications $[6,8,9,11,15$, $18]$ it is possible to find the analysis of sorptive appliances practical usage in industrial applications, enabling to regain the heat from technological processes, waste heat from clinker cooler or the process of sintering and cooling iron-bearing materials in steel plants.

The aim of carrying out the scientific experiment on the possibility of using distribution network heat in summer season to supply double-chamber adsorptive refrigerators was to verify present knowledge on the influence of hot water temperature and the temperature of water in the discharging from the aggregate heat cycle on the Coefficient of Performance and refrigeration power of the appliance. The expected result was to define the dependence describing the tested characteristics, which will be the base to ensure a better stability of the coolant producing process and make the optimization of the parameters in order to use a cooling appliance effectively.

\section{Structure and the way of double chamber cool- ing aggregate functioning}

An adsorptive silica gel cooling aggregate of $7 \mathrm{~kW}$ power value has been used in examination. The appliance consists of two-bed silica gel water adsorption chiller, whose function is to adsorb cooling factor's evaporates. Adsorption is defined as a process of particles, atoms or ions bonding on the surface or a border of physical phases [24]. The adsorption ability depends on the size of the surface separating two phases. Adsorptive aggregates are built of various pairs of adsorbent-adsorbate units. Water is most commonly used as an adsorbate and silica gel - as an adsorbent. Silica gel has several advantages, among others the ability to absorb a large amount of water at low temperatures and the possibility to desorb at temperatures below $90^{\circ} \mathrm{C}$. This medium is durable, nontoxic and noncorrosive [5].

Functioning of an adsorptive, double chamber appliance, whose aggregated diagram is shown in Fig. 1, takes place in two semi-cycles. The first one begins when there is low pressure and low temperature in the adsorber 1 and the adsorbent is saturated with a cooling factor, which means it contains a big amount of water - state A. There is high
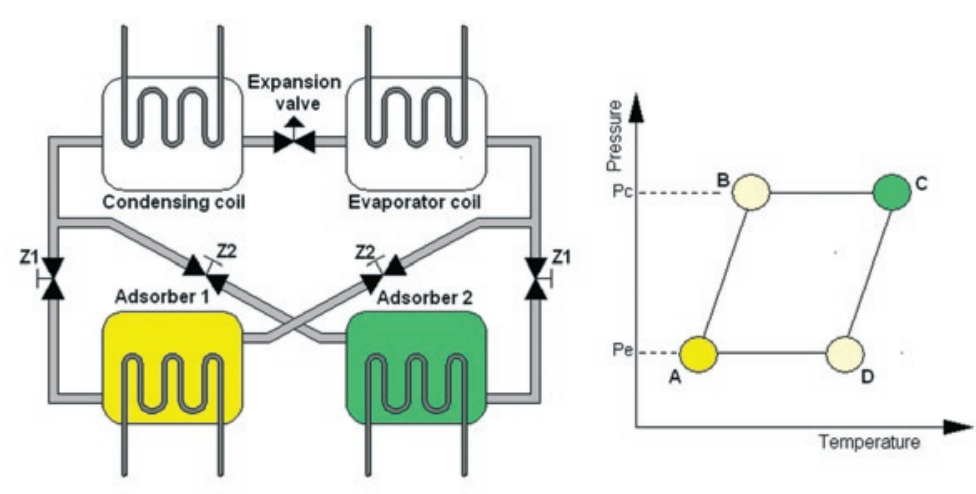

Fig. 1. An aggregated diagram of an adsorptive refrigerator - the initial state of the semi-cycle
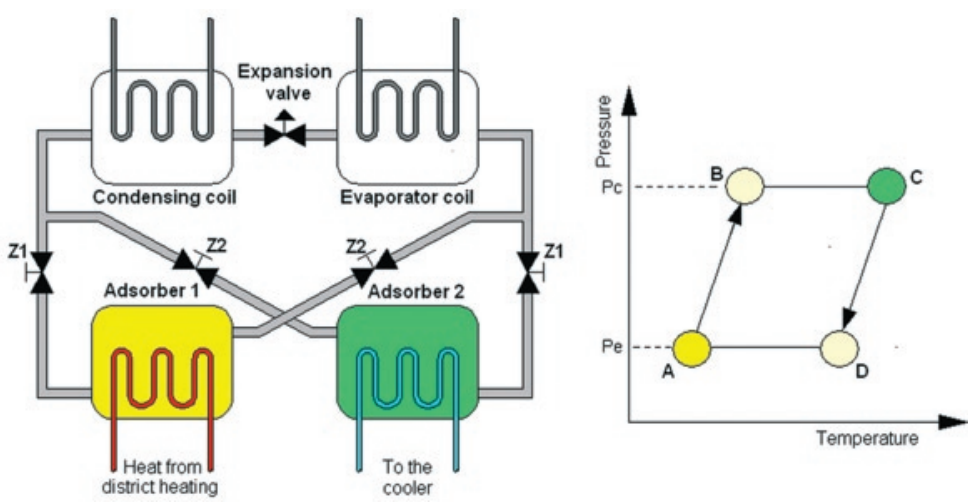

Fig. 2. An aggregated diagram of an adsorptive refrigerator-for a deposit regenerating cycle
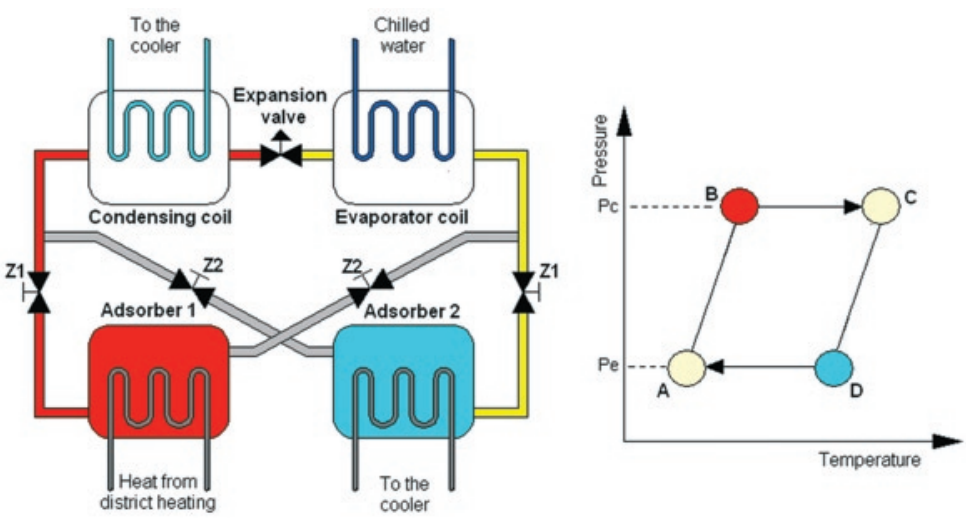

Fig. 3. An aggregated diagram of an adsorptive refrigerator-for a cooling cycle

pressure and high temperature in adsorber 2 and the adsorbent has a minimum contents of water - state $\mathrm{C}$. Valves $\mathrm{Z1}$ and $\mathrm{Z} 2$ are closed.

Fig. 2. shows the state of isosteric deposit 1 heating and isosteric deposit 2 cooling. Heat from heating water cycle is provided to adsorber 1 , which results in the pressure and temperature increase, at a constant humidity of the deposit -curve A-B. Heat receiving by an exchange with a cooling water cycle takes place in adsorber 2 , which causes a fall of temperature and pressure, at a constant humidity of the deposit - curve C-D.

When the pressure in adsorber 1 reaches the value of condensation pressure Ps, and in adsorber 2 it reaches the value of evaporating pressure $\mathrm{Pp}$, valves $\mathrm{Z} 1$, connecting chamber 1 with the condenser and chamber 2 with the evaporator are being opened, which has been shown in Fig. 3. Effective performance of the cooling unit starts for this stage. Regeneration of the sorbent deposit is being done in ad- 
sorber 1 . In a condenser, where heat exchange with cooling water cycle takes place, condensed steam flows through the expansion valve, then evaporating in the evaporator takes the heat from chilled water cycle. The ice water cycle ends up with fan coil unit, where heat is taken from the refrigerated space. Exothermic adsorption process requires discharging the overabundance of heat by cooling water cycle. The adsorber's states vary according to isobaric lines B-C and D-A.

The effective performance is completed when adsorber 1 reaches state $\mathrm{C}$ and adsorber 2 reaches state $\mathrm{A}$, which has been shown in Fig. 4. Valves $\mathrm{Z} 1$ are being closed. The second semi-cycle of the unit functioning starts, when heat is being supplied to adsorber 2 and received from adsorber 1 . In the second semi-cycle a cooling factor flows through a crossing connection of adsorber 2 with the condenser and adsorber 1 with the evaporator. Such a connection is possible by opening valves $\mathrm{Z} 2$. The rest of the process is held identically as in the first semi-cycle.
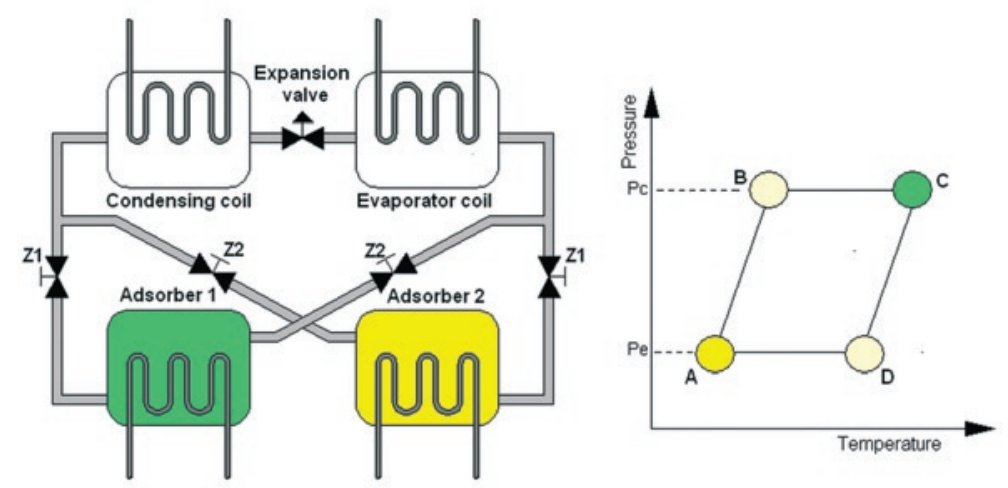

Fig 4. An aggregated diagram of an adsorptive refrigerator - the initial state of the second semi-cycle

\section{Methodology of examinations}

Experimental examinations of heat energy utilization to produce chilled water in an adsorption process have been carried out on an experimental installation consisting of subsystems:

- recording, monitoring and controlling,

- pressure and temperature regulation,

- chilled water production,

- discharging heat overabundance from the installation.

Fig. 5. shows a simplified model of a chilled water production system. Hot water from heat distribution network, whose maximum temperature in summer reaches $70^{\circ} \mathrm{C}$ is the inlet to the system. Ice water used to discharging the heat from the cooling space is the outlet.

In this publication a detailed analysis of functioning of a sorptive cooling aggregate of nominal power $7 \mathrm{~kW}$ has been carried out,

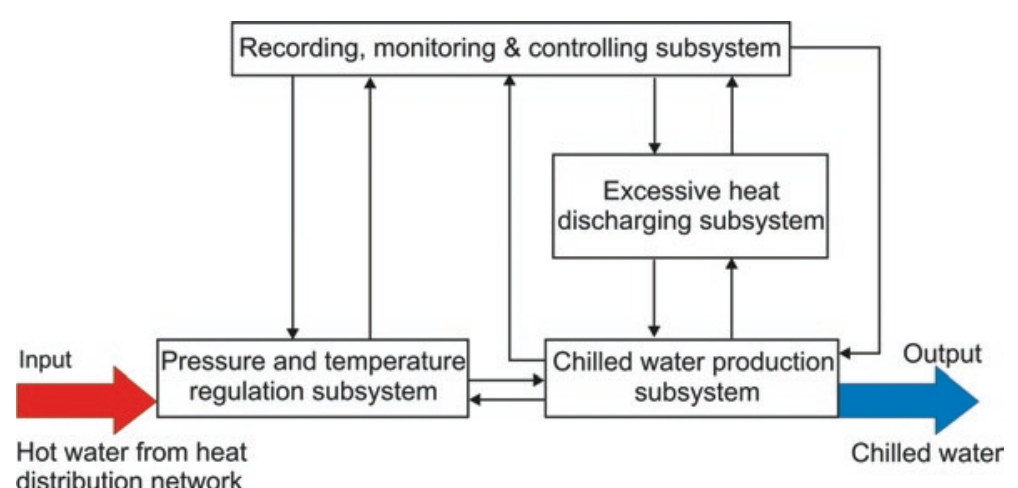

\section{The results of operating examination of an adsorptive cooling aggregate}

The operating examinations have been carried out for hot water supplying the adsorptive aggregate in the range of temperatures TT1 varying from $55^{\circ} \mathrm{C}$ to $70^{\circ} \mathrm{C}$. In the same range recording of chilled water temperatures and water temperatures in the heat discharging from the aggregate cycle has been done. In order to define the efficiency characteristics of a cold production and refrigeration power, the indications from the heat meter on both hot water supplying the aggregate and chilled water have been read out. In the publication the examination results have been depicted for extreme values of hot water in the supplying adsorptive aggregate cycle. Basic examinations of functioning characteristics have been done for water temperature in the heat discharging cycle at a cooling appliance supplying point in the range of $18^{\circ} \mathrm{C}-37^{\circ} \mathrm{C}$.

\subsection{Examination results for water temperatures in the aggregate supplying cycle $T T 1=55 \pm 2.8^{\circ} \mathrm{C}$}

Figure 6 shows Coefficient of Performance distribution as a function of water temperatures in a heat rejection circuit from appliance TT3 for given temperature of hot water supplying a chiller aggregate $T T 1=55 \pm 2.8^{\circ} \mathrm{C}$.

Fig. 5. A simplified model of a coolant production in the process of adsorption 


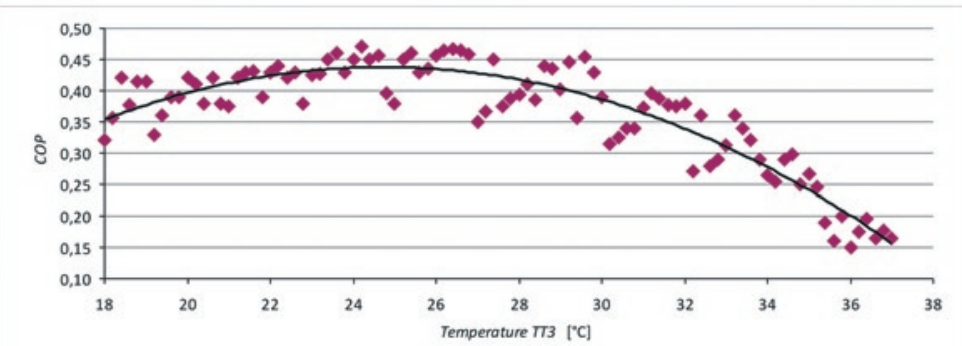

Fig. 6. A diagram of a Coefficient of Performance-COP of an adsorptive aggregate for $T T 1=55 \pm 2.8^{\circ} \mathrm{C}$

The form of a function approximating a Coefficient of Performance distribution from water temperature in the heat discharging from the appliance cycle has been accepted as follows (3):

$$
C O P=-0.002 \cdot(T T 3)^{2}+0.092 \cdot(T T 3)-0,7
$$

The maximum value of efficiency $C O P=0.47$ has been received for water temperature in the heat discharging cycle $T T 3=24.2^{\circ} \mathrm{C}$.

Figure 7 shows cooling power distribution of an adsorptive aggregate $P_{c h}$ for a given range of water temperatures in the heat dis-

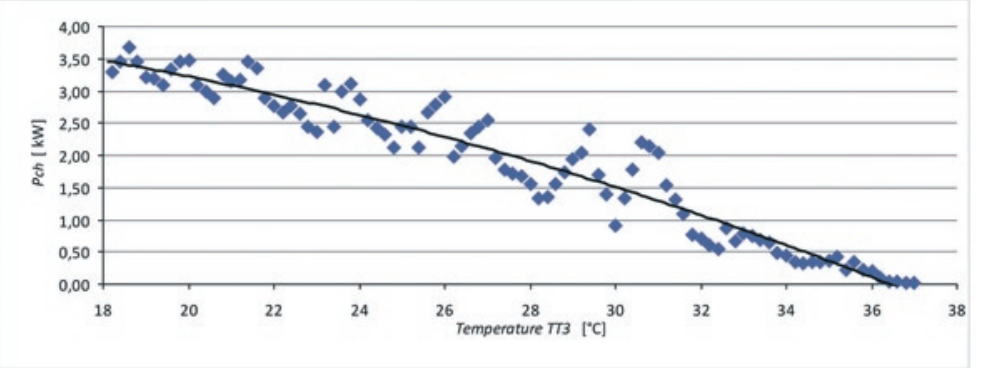

Fig. 7. A diagram of cooling power Pch of an adsorptive aggregate for $T T 1=55 \pm 2.8^{\circ} \mathrm{C}$ temperatures in the heat discharging cycle TT3 for the temperature of hot water supplying a cooling unit $T T 1=55 \pm 2.8^{\circ} \mathrm{C}$.

The form of a function approximating chilled water temperatures from water temperature in the heat discharging cycle has been accepted as follows (5):

$$
T T 2=0.27 \cdot(T T 3)+1.83\left[{ }^{\circ} \mathrm{C}\right]
$$

The temperature of water in the heat discharging cycle is increasing with the increase of chilled water temperature at the aggregate's outlet.

\subsection{Examination results for water temperatures in the aggregate supplying cycle $T T 1=70 \pm 3.7^{\circ} \mathrm{C}$}

Figure 9 shows a diagram of a Coefficient of Performance as a function of water temperature in the heat discharging cycle TT3 for given temperatures of hot water supplying a chilled aggregate $T T 1=70 \pm 3.7^{\circ} \mathrm{C}$.

A relationship between a coolant production efficiency and water temperatures in the heat discharging from the aggregate cycle can be described by a square function, depicted in the form (6):

$$
C O P=-0.001 \cdot(T T 3)^{2}+0.052 \cdot(T T 3)-0.36
$$

The maximum value of efficiency $C O P=0.53$ has been received for water temperature in the heat discharging cycle TT $3=33^{\circ} \mathrm{C}$

The examination of a Coefficient of Performance in an adsorption chiller aggregate presented here indicate a large dependence on water temperature in the heat discharging cycle. With the increase in temperature of the hot water supplying the sorptive cooling appliance, the range of maximum efficiency extends, which results in limiting the influence of water temperature in the heat discharging cycle.

Cooling power distribution $P_{c h}$ of an adsorptive aggregate as a function of water temperature TT3 has been shown in Fig. 10.

\section{charging cycle.}

The form of a function approximating cooling power distribution from water temperature in the heat discharging from the appliance cycle has been accepted as follows (4):

$$
P_{c h}=-0.004 \cdot(T T 3)^{2}+0.021 \cdot(T T 3)+4.34 \quad[\mathrm{~kW}]
$$

The maximum value of cooling power $P_{c h}=3.67 \mathrm{~kW}$ has been received for water temperature in the heat discharging cycle $T T 3=18.6^{\circ} \mathrm{C}$. For temperatures $T T 3 \geq 32^{\circ} \mathrm{C}$ the aggregate cooling power has decreased to the value below $1 \mathrm{~kW}$.

Figure 8 shows chilled water temperatures distribution TT2 on the output of an adsorptive aggregate depending on water

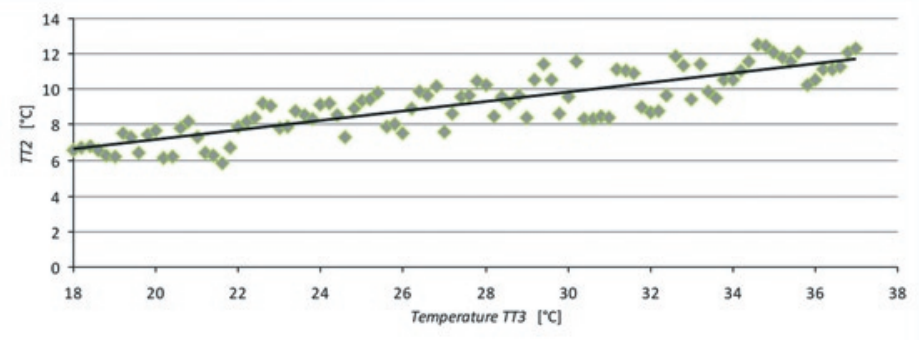

Fig. 8. A diagram of ice water temperatures - TT2 for the temperature of hot water supplying an adsorptive aggregate $T T 1=55 \pm 2.8^{\circ} \mathrm{C}$

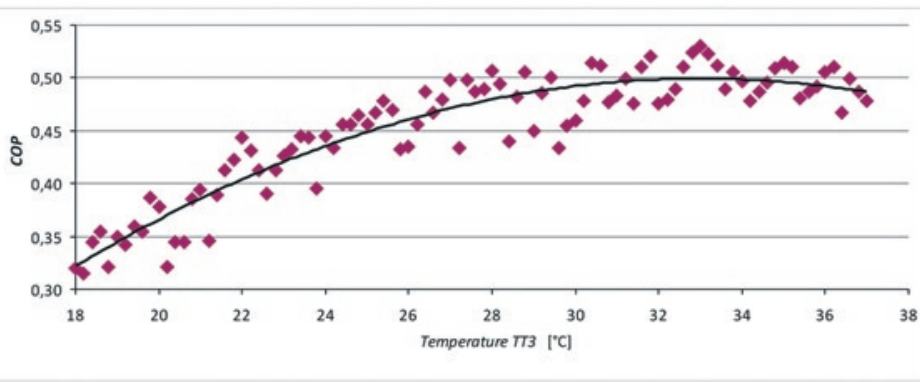

Fig. 9. A diagram of a Coefficient of Performance coolant production efficiency-COP of an adsorptive aggregate $T T 1=70 \pm 3.7^{\circ} \mathrm{C}$

The form of a function approximating cooling power distribution from water temperature in the heat discharging from the appliance has been accepted as follows (7):

$$
P_{c h}=-0.004 \cdot(T T 3)^{2}+0.017 \cdot(T T 3)+6.1 \quad[\mathrm{~kW}]
$$

The maximum value of cooling power $P_{c h}=5.45 \mathrm{~kW}$ for a given range has been received for temperature $T T 3=18.2^{\circ} \mathrm{C}$. The cooling power of the adsorptive aggregate is increasing with the increase in the temperature of the supplying hot water. It is caused by a faster regeneration of a silica gel bed. 


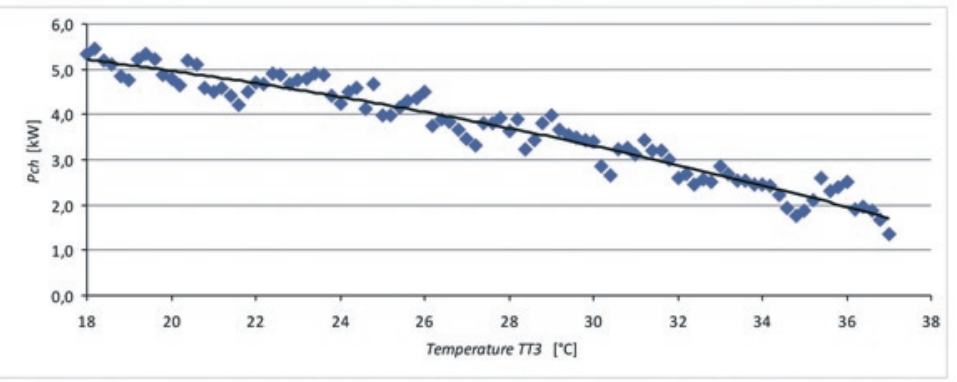

Fig. 10. A cooling power diagram $-P$ ch of an adsorptive aggregate for $T T 1=70 \pm 3.7^{\circ} \mathrm{C}$

Figure 11 shows chilled water temperature distribution TT2 at an adsorptive aggregate's outlet depending on water temperatures in the heat discharging cycle TT3 for the temperature of hot water supplying a cooling unit $T T 1=70 \pm 3.7^{\circ} \mathrm{C}$.

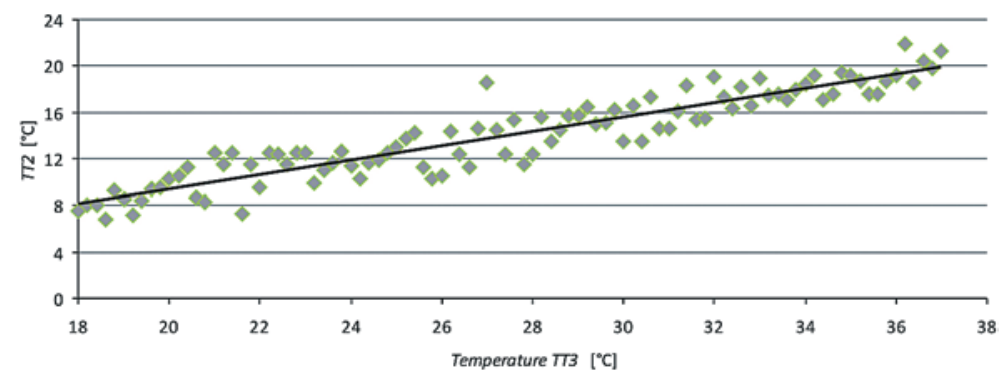

Fig. 11. A diagram of chilled water temperatures TT2 for the temperatures of hot water supplying an adsorptive aggregate $T T 1=70 \pm 3.7^{\circ} \mathrm{C}$

A relationship between ice water temperatures and water temperatures in the heat discharging from the aggregate cycle can be described by a linear function, depicted in the form (8):

$$
T T 2=0.62 \cdot(T T 3)-3.1 \quad\left[{ }^{\circ} \mathrm{C}\right]
$$

For the whole range of carried out examination, the increase in temperature of hot water supplying a sorptive cooling appliance causes an increase in chilled water temperatures.
The examinations have proved the possibility to reach high Coefficient of Performance as well as cooling power of a double chamber cooling aggregate by changing hot water temperature in the supplying cycle of this aggregate. The cooling efficiency and the cooling power can be also changed by changing temperature in the heat discharging cycle. The defined relationship describing the parameters of functioning let us choose between power maximization and efficiency maximization, which, depending on the temperature of the available source of heat allows to utilize effectively a sorptive cooling appliance with lowering exploitation costs at the same time.

\section{Conclusions}

The fall of the demand for network heat in summer season results in underloading of heat distribution networks and affects negatively the all-year-round energy balance of heating companies. It seems possible to utilize heat to supply adsorptive cooling appliances producing chilled water for the needs of air conditioning in order to increase the heat distribution networks' weight in summer season.

By analyzing the examination results, a strong linear correlation between ice water temperatures and water temperatures in the heat discharging from the aggregate cycle has been recorded. Decisive parameters affecting the efficiency and cooling power of the examined appliance are equally hot water temperatures and water temperatures in the heat discharging cycle. The influence of water temperatures in the heat discharging cycle onto the efficiency and cooling power at a certain hot water temperature are described by square functions. The increase in water temperatures in the heat discharging from the appliance cycle causes the fall of cooling power.

Aiming at limiting the influence of water temperatures in the heat discharging cycle, at given cooling power characteristics, water of highest possible temperature should be provided to the adsorptive appliance supplying cycle.

The carried out experiments let us determine basic parameters influencing cooling efficiency, refrigeration power and chilled water temperature of a two bed silica gel water adsorption chiller double chamber adsorptive cooling aggregate. The received results show the possibility to regulate the parameters of the cooling appliance supplied from a heat distribution network more precisely, this way let us lower the costs of exploitation.

\section{References}

1. Allouache N., Chikh S., Bennacer R., Al Mers A. Modelling of heat and mass transfer in an adsorption solar cooling system. Special Topics and Reviews in Porous Media: An International Journal, 2013; 4: 197-205, https://doi.org/10.1615/SpecialTopicsRevPorousMedia. v4.i3.10.

2. Chihara K., Suzuki M. Air drying by pressure swing adsorption. J. Chem. Eng. Japan, 1983; 16(4): 293-299, https://doi.org/10.1252/ jcej.16.293.

3. Chua H.T., Ng K.C., Malek A., Kashiwagi T., Akisawa A., Saha B.B. Modelling the performance of two-bed, silica gel-water adsorption chillers. International Journal of Refrigeration, 1999; 22: 194-204, https://doi.org/10.1016/S0140-7007(98)00063-2.

4. Chua H.T., Ng K.C., Wang W., Yap C., Wang X.L. Transient modelling of a two-bed silica gel-water adsorption chiller. International Journal of Heat and Mass Transfer, 2004; 47: 659-669, https://doi.org/10.1016/j.ijheatmasstransfer.2003.08.010.

5. Gwadera M. Adsorpcja wody na silikażelu w adsorpcyjnych urządzeniach chłodniczych. Inżynieria i Aparatura Chemiczna, 2013; 52(4): 317-318.

6. Gwadera M., Kupiec K. Adsorption cooling as an effective method of waste heat utilization. Chemistry, 2011; 8:61-70.

7. Hokkanen V., Leskinen S., Aastrup B., Hammer F. Nowa technologia chłodu scentralizowanego dla Helsinek i Herning. Ciepłownictwo w Polsce i na Świecie, 1997; 1-2: 26-28.

8. Kantor R. Modelowanie hybrydowego obiegu chłodniczego przy wykorzystaniu program LabView. Zeszyty naukowe Politechniki Rzeszowskiej, 2014; 3: 367-374.

9. Karwat B., Stańczyk E. Koncepcja wykorzystania ciepła odpadowego na przykładzie wybranych procesów technologicznych do wytwarzania wody lodowej na potrzeby klimatyzacji. Chłodnictwo, 2013; 9: 24-27.

10. Karwat B., Stańczyk E., Mazurek M. Wykorzystanie ciepła sieciowego do wytwarzania chłodu w procesie adsorpcji. Chłodnictwo, 2014; 5: 26-29. 
11. Karwat B., Stańczyk E., Swatek M. Układ urządzeń do wytwarzania wody lodowej z wykorzystaniem ciepła z zakładów termicznej utylizacji odpadów. Patent - PL 404298 A1.

12. Khan M.Z.I., Sultana S., Akisawa A., KashiwagiT.Numerical simulation of advanced adsorption refrigeration chiller with mass recovery. Journal of Naval Architecture and Marine Engineering, 2006; 3: 59-67.

13. Lindqvist Land A. Dynamiczny rozwój chłodu sieciowego. Ciepłownictwo w Polsce i na Świecie, 2001; 11-12: 202-203.

14. Miller E.B. The Development of Silica Gel, Refrigerating Engineering in the American Society of Refrigerating Engineers, 1929; 17(4): 103-108.

15. Mira-Hernandez C., Weibel J.A., Groll E.A., Garimella S.V. Compressed-liquid energy storage with an adsorption-based vapor accumulator for solar-driven vapor compression systems in residential cooling. International Journal of Refrigeration, 2016; 64: 176-186, https://doi. org/10.1016/j.ijrefrig.2015.11.015.

16. Pyrka P. Modelowanie trójzłożowej chłodziarki adsorpcyjnej. Zeszyty Energetyczne, 2014, 1: 205-216.

17. Schroeder A., Łach J., Poskrobko S. Przegląd tendencji w zakresie wytwarzania wody lodowej w systemie trójgeneracji. Archiwum Gospodarki Odpadami i Ochrony Środowiska, 2009; 11(3): 63-74.

18. Sekret R., Turski M. A concept for a solar adsorption cooling system. Architecture Civil Engineering Environment, 2012; 5(1): 71-78.

19. Sircar S., Hufton J.R. Why Does the Linear Driving Force Model for Adsorption Kinetics Work? Adsorption, 2000; 6: 137-147, https://doi. org/10.1023/A:1008965317983.

20. Smyk A., Pietrzyk Z. Czy w Polsce istnieje realna szansa na chłód z central zasilanych ciepłem systemowym. Ciepłownictwo,Ogrzewnictwo, Wentylacja, 2010; 41/11: 400-407.

21. Smyk A., Sikora S.: Aspekty możliwości dostarczania ciepła z warszawskiego systemu ciepłowniczego na potrzeby pozyskiwania chłodu w okresie letnim. Ciepłownictwo, Ogrzewnictwo, Wentylacja, 1999; 8: 5-9.

22. Smyk A., Sikora S. Możliwość dostarczania ciepła z systemu ciepłowniczego dla potrzeb pozyskiwania chłodu w okresie letnim. Ciepłownictwo w Polsce i na Świecie, 2000, zeszyt 5-6, str. 76-82.

23. Sourav M., Pramod K., Kandadai S., Pradip D. Development and performance studies of a nair cooled two-stage multi-bed silica gel and water adsorption system. International Journal of Refrigeration, 2015; online.

24. Adsorption, Glossary, The Brownfields and Land Revitalization Technology Support Center, https://brownfieldstsc.org/glossary.cfm? $\mathrm{q}=1$.

\section{Emil STAŃCZYK \\ Bolesław KARWAT \\ Ryszard MACHNIK \\ Jerzy NIEDŹWIEDZKI}

AGH University of Science and Technology

Faculty of Mechanical Engineering and Robotics

Al. Mickiewicza 30, 30-059 Kraków, Poland

E-mail: stanczykemil@gmail.com, karwat@agh.edu.pl,

machnik@agh.edu.pl, jniedz@agh.edu.pl 